\title{
Tolerance of newly sown cocksfoot-clover pastures to the herbicide
} imazethapyr

T.R. LEWIS, R.J. LUCAS, R.W. HOFMANN and D.J. MOOT Lincoln University, Field Research Centre, Faculty of Agriculture \& Life Sciences, PO Box 85084, 7647, Lincoln, New Zealan teresa.lewis@lincolnuni.ac.nz

\section{Abstract}

In New Zealand, subterranean clover is recommended as a companion legume in mixed swards, particularly in dryland cocksfoot-based pastures. However establishment of cocksfoot is slower than perennia ryegrass and therefore weed ingress is more common. An experiment at Lincoln University, Canterbury showed imazethapyr applied when clover was at the 3-4 trifoliate leaf stage, and cocksfoot at the $2+$ leaf stage, increased the subterranean clover content of the pastures by at least $1000 \mathrm{~kg} \mathrm{DM} / \mathrm{ha}$, despite initial visual phytotoxicity responses. Balansa and white clover pasture yields were not different to their unsprayed unweeded controls. Imazethapyr application controlled broadleaf weeds from early in the season. The herbicide application reduced cocksfoot yields by $70 \%$ in early spring, but yields recovered and were not different to the unsprayed unweeded controls at $1350 \pm$ $260 \mathrm{~kg} \mathrm{DM} / \mathrm{ha}$ after grazing. Imazethapyr application improved subterranean clover pastures through an increase in clover content by suppressing weeds and temporarily reducing the rate of cocksfoot growth.

Keywords: subterranean clover, Spinnaker ${ }^{\mathbb{B}}$ herbicide, seedling, white clover, balansa clover

\section{Introduction}

(Trifolium subterraneum) is the

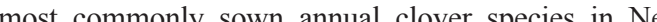
Zealand (Monks et al. 2016; Stewart et al. 2006). Under appropriate management, it can provide gains in quality and dry matter yields of pastures where the performance of perennial legumes is limited by summer dry conditions (Dodd et al. 1995; Smetham 2003). In these regions, cocksfoot (Dactylis glomerata) has been identified as a suitable perennial companion species. For example, the 'MaxClover' grazing experiment from February 2002 until 2011 identified cocksfoot-subterranean clover ('Denmark') mixtures as the most productive and persistent of the dryland pastures tested, with yields second only to lucerne (Medicago sativa) over 9 years (Mills et al. 2014). A field experiment at Lincoln University in 2014 investigated cocksfoot growth with 10 subterranean clover cultivars and found that 'Antas', and 'Narrikup' produced the highest yields at $750 \mathrm{~kg}$ DM/ha by September. By November 'Antas' had yielded 2700 $\mathrm{kg} \mathrm{DM} / \mathrm{ha}$, with 'Narrikup' at $1500 \mathrm{~kg} \mathrm{DM} / \mathrm{ha}$ (Lucas et al. 2015). With appropriate management, establishment ensures productivity and persistence of the pasture for future years. However, cocksfoot is slow to establish compared with most other grasses (Moot et al 2000) an compared with most other grasses (Moot et al. 2000) and while this offers opportunity for the clovers to establish it can also allow weed ingress, particularly when autumn-sown. Therefore, to maximise establishment and yield through to the spring, control after sowing is important. Dear \& Sandral (1999) assessing the phytotoxicity of imazethapyr on seedling lucerne/clover pasture mixes, found yield losses of up to $21 \%$ compared to a weed-free, unsprayed sward but concluded herbicide application was justified as the subterranean clover showed the capacity to recover from the phytotoxicity damage to produce higher seed set.

Imazethapyr is an acetolactate synthase (ALS) inhibiting compound, with symptomatic responses to a r redality (Fedke \& Duke 2004). ALS mhibiting herbicides are both foliar and soil active, and control a wide spectrum of both annual and perennial grass and broadleaf weed at low dosages (Cobb \& Reade 2010). Imazethapyr applied at a rate of $75 \mathrm{~g} /$ ha to annual ryegrass (Lolium multiflorum) plants at the 3-4 leaf stage has been shown to suppress growth by $16-54 \%$ (Clemmer $e$ al. 2004). Another experiment found full recovery Jegras (Lolumperen has been observed following mazethapyr application at $25 \mathrm{~g}$ /ha, while the annua yegrass (Lolium rigidum) showed susceptibility (Dea et al. 2006).

Currently there is little specific information available on newer herbicide options to control broadlea weeds when establishing subterranean clover pastures in New Zealand (Teixeira et al. 2015). The most

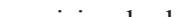
the potential for aiding establishment of subterranean clover by eliminating weeds was Raptor ${ }^{\circledR}$ (a.i. 700 $\mathrm{g} / \mathrm{kg}$ imazamox) (Sandral \& Dear 2005), an ALS nhibiting herbicide which was also recommended by Australian pasture scientists (L. Bell pers. comm.). As Raptor is not, and will not become commercialised in New Zealand, Spinnaker ${ }^{\circledR}$ (a.i. $240 \mathrm{~g} / \mathrm{L}$ imazethapyr), also an ALS inhibiting herbicide was identified to be 


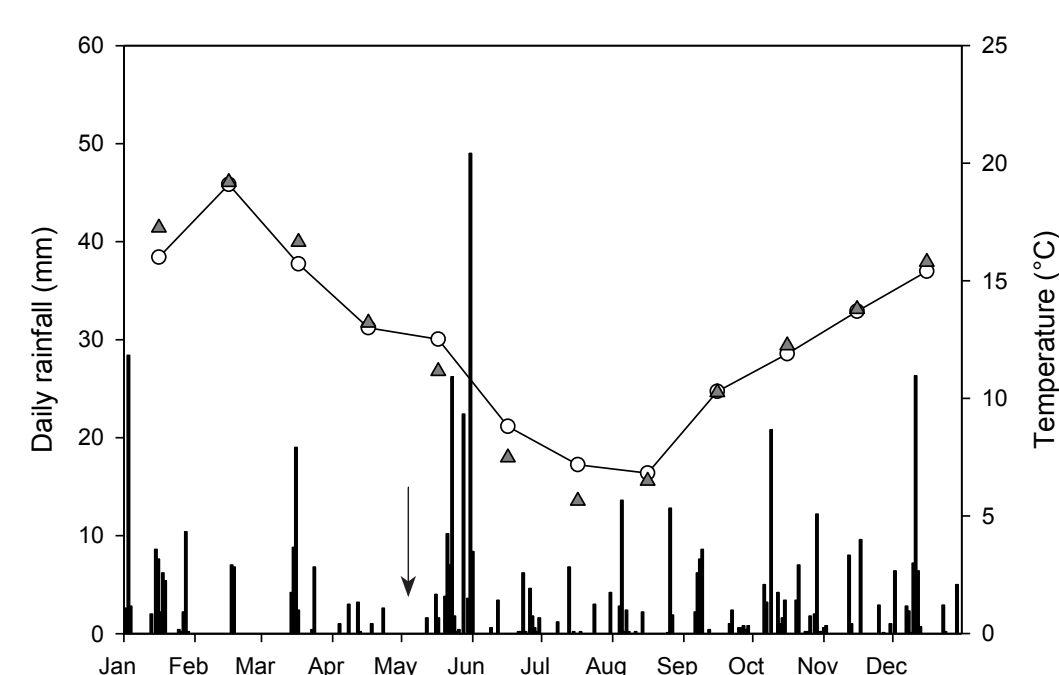

rows. Cultivar plots were 8 x $2.1 \mathrm{~m}$, with five replicates in a randomised complete block design. Cultivar plots were split into three plots of $2.6 \times 2.1 \mathrm{~m}$ for herbicide application in strips across the plots. This created a strip-split plot (criss-cross plot) design (Montgomery 2013).

The site received an accumulated rainfall of 346 $\mathrm{mm}$ over the experimental period from March to October 2016 (Figure 1). However, rainfall in April following herbicide application was only 11 app, 44 mm below $\mathrm{mm}, 44$ mm below the long term average (Table 1 ). Jan lary - December 2016, from lversen 2 datalogger (temperature) and Boadfields January -Docember 2016, from Iversen 2 datalogger (temperature) and Broadher Therefore, plots were irrigated with approximately 20
mm on 13 May 2016, using a RM 540 gx pivot irrigator, to represent a more 'normal' autumn.

Seedling emergence commenced on 25 March 2016, and a representative $1 \mathrm{~m}$ section of drill row was permanently marked in the centre of each subplot. On 7 April 2016, when clover plants were at the $3-4$ tifelite leaf stage and cockfoot sedlings were 3-4 tifol 2 (ef (4) inate of $96 \mathrm{~g}$ a.i./ha $\left(400 \mathrm{ml} / \mathrm{ha} \mathrm{Spinnaker}^{\mathbb{R}}\right)$, with $50 \mathrm{ml} / \mathrm{L}$

Table 1 Monthly long-term averages from 1960 to 2015 for mean $\left(T_{\text {mean }}\right)$ air temperature, rainfall, and Penman potential evapotranspiration (PET). Taken from Meteorological Station, Lincoln, Canterbury.

An experiment was conducted in Iversen field 1 at Lincoln University, Lincoln, Canterbury, New Zealan at the site is predominantly a Wakanui silt loam (Cox 1978), a deep, stoneless, poorly draining soil (Hewit 2010). The site was used as non-renewed pasture and was grazed over the past 20 years.

On 22 February 2016, the site was sprayed out with 5 L/ha Buster ${ }^{\mathbb{B}}$ herbicide $(200 \mathrm{~g}$ a.i./L glufosinateammonium) in $200 \mathrm{~L}$ water to kill the residen vegetation in preparation for direct- drilling into a weedfree undisturbed surface. Subterranean clovers 'Antas' (thousand seed weight (TSW) $11.06 \mathrm{~g}$ ), 'Denmark' (TSW $6.92 \mathrm{~g}$ ), and 'Narrikup' (TSW $9.16 \mathrm{~g}$ ) were sown separately at $20 \mathrm{~kg}$ /ha while, 'Nomad' white clover (TSW 1.08 g) (Trifolium repens) and 'Bote' balan (TSW 1.04 ) (Tifolim repens and 'Bolta' balansa (TSW $1.04 \mathrm{~g}$ ) (Thifolum michelianum) clover were sown at $10 \mathrm{~kg} / \mathrm{ha}$. Sowing rates were above commercia recommendations to maximise legume seedling density and ensure adequate populations for treatments. Clovers were direct-drilled on 1 March 2016 into soil with $2 \mathrm{~kg} / \mathrm{ha}$ of 'Greenly II' cocksfoot (TSW $1.02 \mathrm{~g}$ ) using a Flexi-seeder ${ }^{\mathbb{B}}$ drill at $2 \mathrm{~cm}$ depth in $15 \mathrm{~cm}$ drill

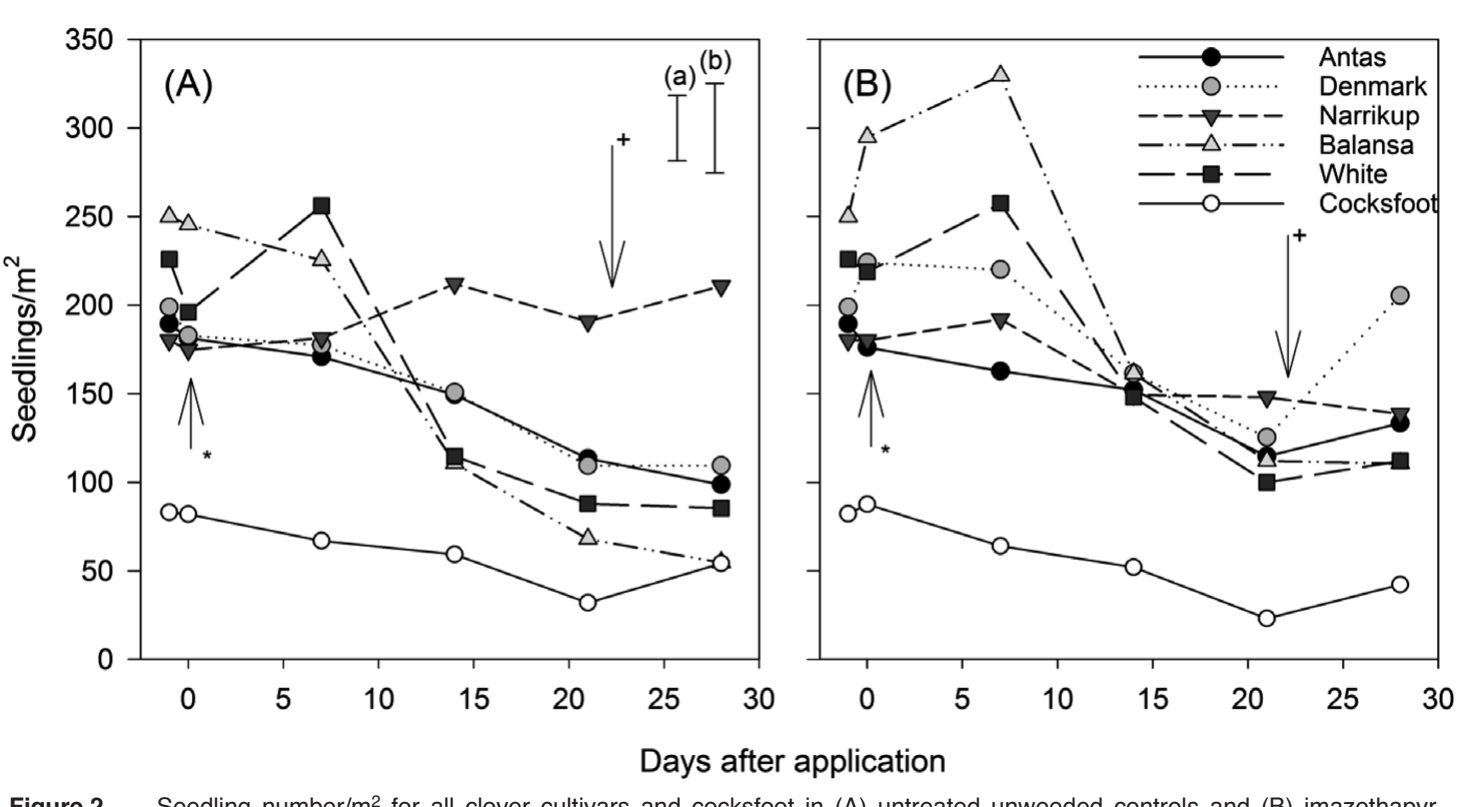

Figure 2 Seedling number $/ \mathrm{m}^{2}$ for all clover cultivars and cocksfoot in (A) untreated unweeded controls and (B) imazethapyr (B) herbicide $20 \mathrm{~mm}$ irrigation.

Hasten $^{\mathrm{TM}}(704 \mathrm{~g} / \mathrm{L}$ ethyl and methyl esters of vegetable oil). Herbicide was applied using a knapsack sprayer with a $2 \mathrm{~m}$ width in strips at right angles across the cultivar plots, leaving a $2 \mathrm{~m}$ unsprayed, unweeded control strip in each plot, randomised for each replicate. Wind direction at spraying was a prevailing northerly, with an average speed $8-12 \mathrm{~km} / \mathrm{h}$ for the duration of application. Average air temperature was $17.9^{\circ} \mathrm{C}$, and average soil temperature at $2 \mathrm{~cm}$ depth was $15.7^{\circ} \mathrm{C}$.

Seedling counts of sown clover for each plot were carried out weekly until one month post-herbicide application, when the seedling counts were stable. All plots were visually scored on 2, 5, 7, 10 and 14 days after application (DAA) and weekly thereafter until the

Table 2 European Weed Research Society (EWRS) phytotoxicity damage score.

Score Damage symptoms

No damage / healthy plants

Very mild symptoms

Slight, but clearly visible symptoms

Severe visible damage, e.g. chlorosis, which do not

lead to a negative effect on yield

Thinning, severe chlorosis, leaf burn or suppression,

some yield reduction expected

6-9 Above commercial threshold, symptoms range from severe damage to total plant death.

(OEPP/EPPO 2014) first harvest, using the EWRS phytotoxicity scoring system (Table 2).

Plots were sampled for biomass on 9 September and 27 October 2016 by cutting $0.2 \mathrm{~m}^{2}$ samples with electric clippers to grazing height from the centre of each plot. A subsample of $\sim 50 \mathrm{~g}$ fresh weight was sorted into sown clover, cocksfoot, broadleaf weed, grass weed and dead matter components. Samples were then oven-dried for at least 48 hours at $60^{\circ} \mathrm{C}$ and weighed. Plots were for from the 12 September 2016 following the first harvest. Post-grazing the residual herbage was cut and carried using a Fieldmaster forage harvester and cage to remove the unpalatable weeds, particularly from the unsprayed controls. This enabled regrowth to be isolated and measured in the October harvest. Results were analysed using a two-way split-strip plot ANOVA of cultivar by herbicide, with herbicide as rows and cultivar as columns using Genstat 16.1. Repeated measures ANOVAs of . seedling counts and EWRS score we used to analyse changes over time. When significan, Fisher's protected Least Significant Difference (LSD) tests were used to separate means at $\alpha=0.05$.

\section{Results}

\section{Seedling establishment}

Seedling numbers of all sown clover before herbicide application were $210 \pm 20 / \mathrm{m}^{2}$ and not different $(\mathrm{P}=0.080)$ among cultivars. Clover numbers reduced $(\mathrm{P}<0.001)$ over the 28 day measurement period post-herbicide application (Figure 2). There were differences among 


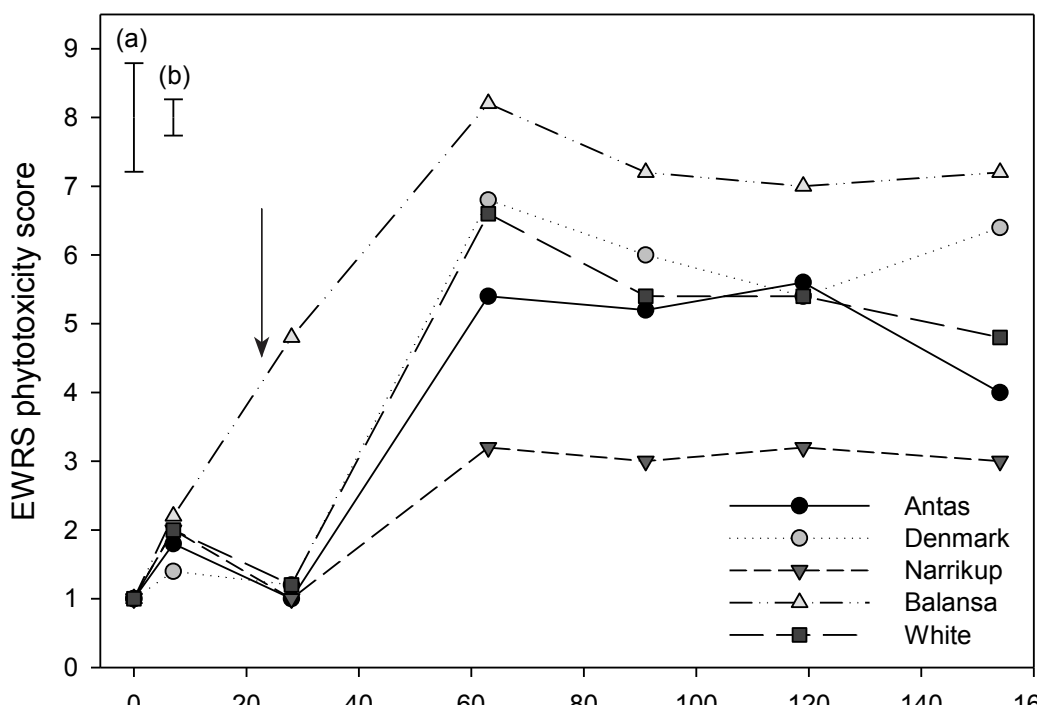

Days after application

Figure 3 EWRS phytotoxicity scores (relative to untreated controls) for all imazethapyr treated plots from applicalion on 7 April 2016 to first harvest on 9 September 2016 interaction at a single time point. Dotted line indicates commercial EWRS score threshold; arrows indicates application of $20 \mathrm{~mm}$ irrigation.

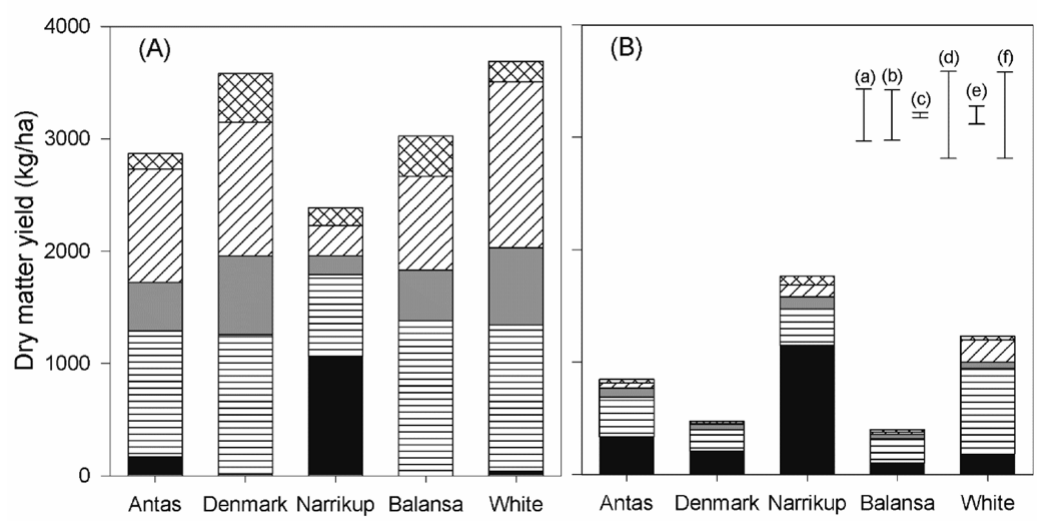

Figure 4 Mean dry matter yields and composition for growth of five clover cultivars at the first harvest on 9 September 2016 at Iversen 1, Lincoln University, Canterbury, New Zealand for sown clover $(\mathbf{\square})$, cocksfoot $($ (i) $)$, broadleaf weed $(\square)$, grass weed (2) and dead matter ( components of cultivar plots. (A) is unsprayed, unweeded controls, and (B) is imazethapyr treatments. Error bars are LSD for main effect of (a) cultivar on clover yield; (b) herbicide on cockstoot; (c) herbicide on broadlea weeds; (d) herbicide on grass weeds; (e) herbicide on dead matter; (f) herbicide on
total dry matter yields.

cultivars $(\mathrm{P}<0.001)$ over time, but no effect $(\mathrm{P}=0.537)$ of imazethapyr application on seedling number $/ \mathrm{m}^{2}$. Balansa and white clover at $85-100 \pm 29$ seedlings $/ \mathrm{m}^{2}$ had lower densities after the measurement period than 'Denmark' and 'Narrikup' at 155-175 \pm 29 seedlings/ $\mathrm{m}^{2}$, while 'Antas' at $115 \pm 29$ seedlings $/ \mathrm{m}^{2}$, was not different to any of the cultivars, but was reduced compared with preapplication seedling numbers (Figure 2)

Cocksfoot seedling numbers at $85 \pm 9$ seedlings/ $\mathrm{m}^{2}$ were not different among treatments $(\mathrm{P}=0.785)$ or cultivars $(\mathrm{P}=0.357)$ before herbicide application (Figure 2) Cocksfoot (Figure 2) Cocksfoot seedling numbers reduced $(\mathrm{P}<0.001)$ over time to 55 \pm 8 seedlings $/ \mathrm{m}^{2}$, but there was no effect of cultivar $(\mathrm{P}=0.387)$ or herbicide application $(\mathrm{P}=0.993)$ on this reduction.

\section{Phytotoxicity assessment} EWRS scores for imazethapyr-treated balansa clover showed less tolerance, with a score of 5.0 by 28 DAA, which increased $(\mathrm{P}<0.001)$ to a final score of 7.0 by 154 DAA (Figure 3). All other imazethapyr treated cultivars were not different to their unsprayed controls at 28 DAA, but all EWRS scores had increased by 63 DAA, with only 'Narrikup', at 3.0 scoring lower than 5.0. By 153 DAA, 'Antas' and white clover had recovered $(\mathrm{P}<0.001)$ with EWRS scores of $4.0-5.0$ (Figure 3).

Harvest 1: 9 September 2016

At the first harvest, sown clover yields were not different $(\mathrm{P}=0.125)$ between imazethapyr and the unsprayed unweeded control (Figure 4). 'Narrikup' clover yields of $1100 \mathrm{~kg} \mathrm{DM} / \mathrm{ha}$ were higher $(\mathrm{P}=0.006)$ than all other cultivars which produced $<250 \mathrm{~kg}$ DM/ha Sown cocksfoot grass yields in imazethapyr treated plots were $<350 \mathrm{~kg} \mathrm{DM} / \mathrm{ha}$, and lower $(\mathrm{P}=0.003)$ than unsprayed controls at $1100 \mathrm{~kg} \mathrm{DM} / \mathrm{ha}$. Broadleaf weed yields of imazethapyr treatments were $<50 \mathrm{~kg} \mathrm{DM} / \mathrm{ha}$, which was less than their respective unsprayed controls with $400 \mathrm{~kg} \mathrm{DM} / \mathrm{ha}$. Broadleaf weeds identified were broadleaved dock (Rumex obtusifolius), clustered dock ( $R$. conglomeratus) chickweed (Stellaria media), dandelion (Taraxacum officinale), fathen (Chenopodium album), hawksbeard (Crepis capillaris), mallow (Malva nicaeensis), spurrey (Spergula arvensis), twin cress (Lepidium didynum) wireweed (Polygonum aviculare), and yarrow (Achillea millefolium) Only broadleaved and clustered dock remained in the imazethapyr treatments, and these were stunted in size.

Grass weed yields of $<100 \mathrm{~kg} \mathrm{DM} / \mathrm{ha}$ were lower $(\mathrm{P}=0.014)$ in imazethapyr in plots than their untreated unweeded controls at 1100 $\mathrm{kg} \mathrm{DM} / \mathrm{ha}$ (Figure 4). Grass weeds identified were annual ryegrass, phalaris (Phalaris aquatica), and annual brome (Bromus hordeaceus).

Harvest 2: 27 October 2016

By the second harvest, clover yields were higher $(\mathrm{P}=0.001)$ at $750-1800 \mathrm{~kg}$

$\mathrm{DM} / \mathrm{ha}$ in the sprayed plots than in their respective controls (Figure 5). The exception was balansa clover, which had no difference in yield between treatments at $<100 \mathrm{~kg} \mathrm{DM} / \mathrm{ha}$. Sown cocksfoot grass yields were $1000-1650 \mathrm{~kg} \mathrm{DM} / \mathrm{ha}$ after September grazing and were not different $(\mathrm{P}=0.099)$ between imazethapyr and the controls. Broadleaf weed yields were $100-250 \mathrm{~kg} \mathrm{DM} /$ ha with no difference $(\mathrm{P}=0.128)$ between imazethapyr and the controls. Grass weed yields were higher $(\mathrm{P}=0.005)$ in controls, with $1300 \mathrm{~kg} \mathrm{DM} / \mathrm{ha}$, while imazethapyr treatments had $250 \mathrm{~kg} \mathrm{DM} / \mathrm{ha}$. Remaining grass weeds were predominantly annual ryegrass.

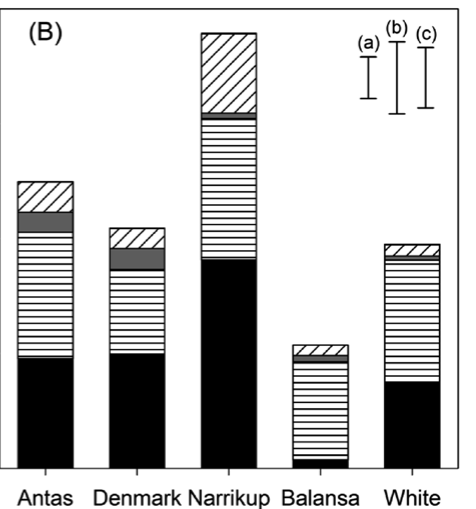

A

Mean dry matter yields and composition for growth of five clover cultivars at harvest 2 on 27 October 2016 at Iversen 1, Lincoln University, Canterbury, New Zealand mattr ( matter ( components of cultivar plots. (A) is unsprayed, unweeded controls, and (a) sown clover; (b) grass weeds; (c) total dry matter yields.

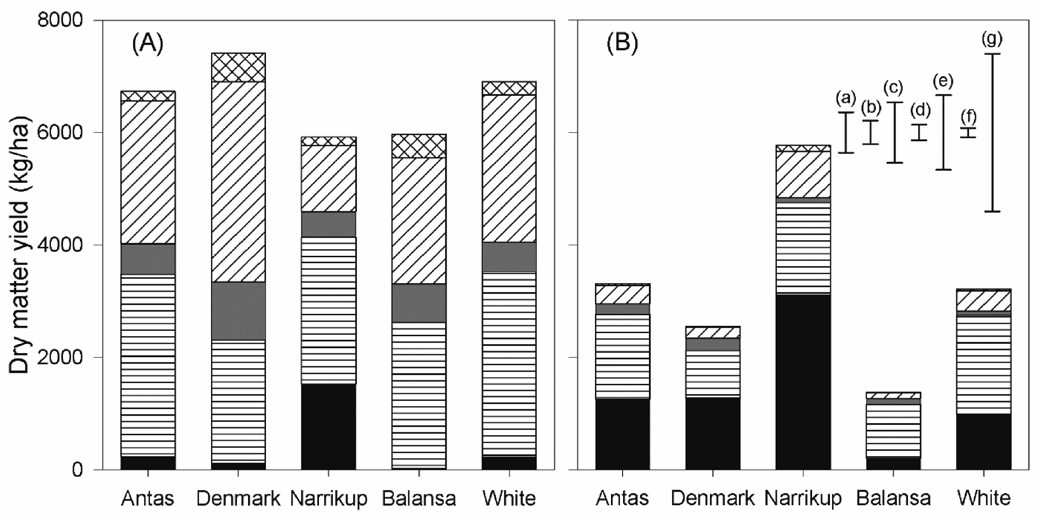

Total mean dry matter yields and composition for growth of five clover cultivars from 1 March to 27 October 2016 at lversen 1, Lincoln University, Canterbury, New (ख) and dead matter (浛) components of cultivar plots. (A) is unsprayed, unweeded controls, and (B) is imazethapyr treated plots. Error bars are LSD for (a) main effec effect of herbicide on yeilds; (b) main effect of herbicide on clover yields; (c) main yields: (e) main effect of herbicide on grass weed yields; (f) main effect of herbicide on dead matter; (g) cultivartherbicide interaction for total dry matter yields.

\section{Total season yields}

Total dry matter yields (harvest 1 plus harvest 2) for the season showed a cultivar $\mathrm{x}$ herbicide interaction, with only imazethapyr treated 'Narrikup' producing the same total DM as its control with $6000 \mathrm{~kg} \mathrm{DM} / \mathrm{ha}$ (Figure 6). Imazethapyr treated 'Antas', 'Denmark', white, and balansa clovers produced total DM yields ower $(\mathrm{P}=0.021)$ than their controls.

Sown clover yields of 'Narrikup' were higher $(\mathrm{P}=0.001)$ than all other cultivars. Imazethapyr treated 'Narrikup' produced $3100 \mathrm{~kg}$ DM/ha sown clover, which was greater $(\mathrm{P}<0.001)$ than its control at 1500 

$\mathrm{kg} \mathrm{DM} / \mathrm{ha}$. Sown clover yields of imazethapyr treated
'Denmark' and 'Antas' yielded 1250-1275 $\mathrm{kg} \mathrm{DM}$ ha, and were greater $(\mathrm{P}<0.001)$ than their unsprayed controls with $120-230 \mathrm{~kg} \mathrm{DM} / \mathrm{ha}$. White and balansa clovers were consistently the lowest $(\mathrm{P}=0.001)$ yielding clovers, and not different $(\mathrm{P}<0.001)$ to their controls.

Sown cocksfoot grass yields were lower $(\mathrm{P}=0.013)$ in imazethapyr treatments, at $1300 \mathrm{~kg} \mathrm{DM} / \mathrm{ha}$, than in the controls with $2800 \mathrm{~kg} \mathrm{DM} / \mathrm{ha}$ (Figure 6). This reduction was not consistent for the season, and only an early response to imazethapyr treatment (Figure 4) as the yields recovered to be not different by the second harvest (Figure 5).

Broadleaf weed yields were $150 \mathrm{~kg} \mathrm{DM} / \mathrm{ha}$ for imazethapyr treated plots, lower $(\mathrm{P}=0.002)$ than the unsprayed controls with $650 \mathrm{~kg} \mathrm{DM} / \mathrm{ha}$. Grass weed yields were consistently reduced $(\mathrm{P}=0.006)$ by imazethapyr treatments with $350 \mathrm{~kg} \mathrm{DM} / \mathrm{ha}$, and only the annul ryegrass remained, compared with the unsprayed control at $2400 \mathrm{~kg}$ DM/ha containing annual ryegrass, brome and phalaris.

\section{Discussion}

Phytotoxicity effects and sown clover yield Sown balansa and white clover had lower seedling numbers following establishment compared to the three subterranean clover cultivars, which sustained minima seedling losses over the 28 days (Figure 2). This failure to thrive both in the control and after imazethapy application suggests that balansa and white clover were unable to establish as successfully with cocksfoot in the dry autumn conditions, despite the elimination of weeds. Thus the imazethapyr treatment failed to provide them with an advantage in the dry environment despite broadleaf weed control.

EWRS scores showed that clover cultivars responded differently to imazethapyr treatment (Figure 3). 'Narrikup' was the only cultivar with a final EWRS score of 3.0 , which was higher than the control, but lower than the threshold of 5.0 from which plants are expected capable of recovery. This low EWRS score for 'Narrikup' was associated with only mild phytotoxicity symptoms as a result of imazethapyr treatment on the cultivar in these conditions, and a September harves yield for the clover component the same as the unweeded control. This September yield was more than four times higher than the yields for all other clover cultivars. In contrast, the high EWRS scores of 'Denmark' and balansa clover (Figure 3) indicates that they were affected by imazethapyr application. 'Antas' and white clover showed less effect of the herbicide. Despite the indications provided by the EWRS scores across these four cultivars, their early spring yields were consisten at $<250 \mathrm{~kg} \mathrm{DM} / \mathrm{ha}$, with no differences between the sprayed and unsprayed plots (Figure 4). Phytotoxicity effects of imazethapyr were not easily visible on the white and balansa clover plants, but were marked as a reduction in plant number, while subterranean clover effects primarily presented as discolouration and leaf distortion. Confounding of the EWRS system has been noted by Dear \& Sandral (1997), with symptoms such as leaf distortion providing a less reliable indication of yield loss.

The yields of all subterranean clover cultivars were lower than expected for a March sowing date, as midSeptember yields for subterranean clover monocultures of $7000 \mathrm{~kg} \mathrm{DM} /$ ha have been measured at this site (Moot et al. 2003). These yields were observed in irrigated, hand-weeded environments, and illustrate the impact of the late autumn rain in the current experiment. It seems that the low rainfalls in March following establishment, and in April following treatment application affected the growth rate of 'Antas' and 'Denmark' more severely than that of 'Narikup'. The highe phytotoxity her phytotoxicity response of 'Antas' may be a result of its larger seedling leaf size, allowing greater herbicide absorption than the 'Narrikup', which has a more pubescent leaf and petiole, which could afford it an additional barrier to herbicide absorption

There was no residual effect of imazethapyr on subterranean clover after grazing, following the early spring harvest. After 1 month of recovery postgrazing, imazether treated 'Narikup' was agan the highest yieldig (Figuethapyr treated hite clover recovered despite initial low yields, as has been previously reported in Australian evaluations of various subterranean clover cultivars (Dear et al. 1995; Sandral \& Dear 2005). This recovery is indicative of a variation of susceptibility of subterranean clover cultivars to the foliar activity of imazethapyr, but no susceptibility to the 6 month residual soil activity (BASF 2011). In contrast, the failure of baliva clover to recover (Figure 5) shows shows that imazethapyr did not provide the establishing balansa clover and cocksfoot pasture mix with an advantage over the control, and potentially prevented subsequent emergence during the experimental period.

\section{Cocksfoot}

Imazethapyr application had no effect on cocksfoot seedling numbers, but appeared to reduce growth rates, with higher early-season co in the unsprayed controls (Figure 4). Despite this, the cocksfoot recovered from the effect of imazethapyr after grazing in the late October harvest (Figure 5). This shows that the effect of imazethapyr on cocksfoot at this site was temporary, with no long-term yield reduction. Previous studies (Clemmer et al. 2004; Dear et al. 2006) confirmed initial phytotoxicity responses of before subterranean clover set seed for the season would have provided feed after the subterranean clover life cycle had ended, and the pasture could continue to be grazed through the summer.

\section{Broadleaf weed control}

Imazethapyr markedly reduced broadleaf weeds in the early season by more than $85 \%$, with $<50 \mathrm{~kg}$ $\mathrm{DM} / \mathrm{ha}$ remaining (Figure 4). Following grazing, remaining broadleaf weeds recovered and were not different between sprayed and unsprayed plots in the later harvest (Figure 5). It is likely that interspecific competition for light occurred in the control plots between cocksfoot and the broadleaf weeds. The dense grass canopy appeared to suppress the later growth of the broadleaf weeds following grazing and mowing. Despite this broadleaf weed suppression, clover yields in the controls were not higher as the grass also outcompeted the sown clover species.

\section{Grass weed control}

Brome and phalaris grass weeds were eliminated by the imazethapyr application (Figure 4), while annu ryegrass persisted after imazethapyr application, bu remained supressed (Figure 5). This control of annual ryegrass is in line with previous observations (Clemmer et al. 2004), however, its lack of recovery following grazing compared with the cocksfoot (Figure 5) suggests it was not as tolerant of imazethapyr treatment at the applied rate as the sown cocksfoot.

\section{Total dry matter yield}

Total DM yields for the 2016 growing season were dependent on how the sown clover cultivar tolerated imazethapyr treatment, because the other components only had a primary response to herbicide treatment, with no significant differences between cultivars (Figure 6). Imazethapyr treated 'Narrikup' yielded $6000 \mathrm{~kg}$ $\mathrm{DM} / \mathrm{ha}$ with $50 \%$ clover. This was the only sprayed treatment that yielded the same as the control, but controls contained only $25 \%$ clover. The increase in clover content in the imazethapyr treated 'Narrikup' yields was offset by reductions in cocksfoot $(15 \%$, broadleaf $(8 \%)$, and grass weeds $(5 \%)$. Total DM yields for imazethapyr treated 'Antas' and 'Denmark' were reduced by $50 \%$ compared with their controls, in controls. This shows that the removal of broadleaf weeds and the reduction in grass when the clover was in the seedling phase reduced competitio and allowed them to thrive. The increased seedling survival of subterranean clover could be expected to provide high quality feed for lactating ewes and lambs (Smetham 2003; Ates et al. 2006) and lead to greater seed set, which is vital for the persistence of subterranean clover in later years (Smetham 2003).

The autumn of 2016 was dry, with less than $50 \mathrm{~mm}$ of rainfall including irrigation through emergence and treatment application. This experiment has therefore investigated the effect of imazethapyr in a difficult pasture establishment scenario. With higher rainfalls faster growth was expected with yields more in line with those observed by Moot et al. (2003). With faster growth, herbicide action on broadleaf weeds would

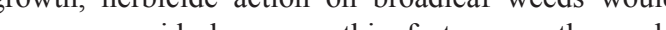
also occur in the sown components. This increase in metabolism could also mean increased herbicide uptake, potentially affecting the ability of the sown cocksfoot and subterranean clover to recover fully, and should be investigated further.

\section{Conclusions}

Seasonal yields of sown subterranean clover increased with imazethapyr herbicide treatment at the 3-4 trifoliate leaf stage, and broadleaf weeds were well-controlled from the seedling stage. All subterranean clover cultivars yielded at least $1000 \mathrm{~kg}$ $\mathrm{DM} /$ ha more clover than their unsprayed, unweeded controls. Grass weeds were well controlled, and remained controlled, while cocksfoot growth was initially checked by the herbicide, but it recovered from the early yield depressions later in the season after grazing. Weed control was effective to inprove the overall legume content of the subterranean clove pastures, but there were significant difference between subterranean clover cultivars and their susceptibility to imazethapyr.

\section{ACKNOWLEDGEMENTS}

Mr Roland Stead for providing the funding for this study, PLSC321 students for helping with the harvest, Annamarie Mills for statistical advice, and the reviewers for their time spent improving this manuscript.

\section{REFERENCES}

Ates, S.; Brown, H.E.; Lucas, R.J.; Smith, M.C.; Edwards, G.R. 2006. Effect of ewe stocking rate in spring on subterranean clover persistence and lamb liveweight gain. Proceedings of the New Zealand Grasslands Association 68: 95-99.

BASF. 2011. Spinnaker ${ }^{\circledR}$ specimen label. P.O. Box 407 , Auckland 1140, New Zealand: BASF New Zealand Limited.

Clemmer, K.C.; York, A.C.; Brownie, C. 2004 Italian ryegrass (Lolium multiflorum) control in imidazolinone-resistant wheat. Weed Technology 18 : 481-489.

Cobb, A.H.; Reade, J.P.H. 2010. Herbicides and plant physiology. $2^{\text {nd }}$ Edition. United Kingdom: WileyBlackwell. 
Cox, J.E. 1978. Soils and agriculture of part Paparua County, Canterbury, New Zealand. New Zealand Soil Bureau Bulletin 34: 128 pp.

Dear, B.S.; Sandral, G.A. 1997. Subterranean clover in NSW - identification and use. Agfact P2.5.16 Dubbo, New South Wales: NSW Agriculture.

Dear, B.S.; Sandral, G.A. 1999. The phytotoxicity of the herbicides bromoxynil, pyridate, imazethapyr and a bromoxynil + diflufenican mixture on subterranean clover and lucerne seedlings. Australian Journal of Experimental Agriculture 39: 839-847.

Dear, B.S.; Sandral, G.A.; Coombes, N.E. 1995 Differential tolerance of Trifolium subterraneum L. (subterranean clover) cultivars to broadlea herbicides 1. Herbage yield. Australian Journal of Experimental Agriculture 35: 467-474.

Dear, B.S.; Sandral, G.A.; Wilson, B.C.D. 2006. Tolerance of perennial pasture grass seedlings to pre-and post-emergent grass herbicides. Animal Production Science 46: 637-644.

Dodd, M.B.; Sheath, G.W.; Tarbotton, I.S. 1995. Development of subterranean clover (Trifolium subterraneum L.) genotypes for New Zealand pastures 3. Whatawhata production evaluation. New Zealand Journal of Agricultural Research 38: 57-63. Fedtke, C.; Duke, S.O. 2004. Herbicides. pp. 247-330. In: Plant toxicology. Eds. Hock, B.; Elstner, E. F. $4^{\text {th }}$ Ed., New York: CRC Press.

Hewitt, A.E. 2010. New Zealand Soil Classification. $4^{\text {th }}$ Ed. New Zealand: Manaaki Whenua-Landcare Research New Zealand Limited.

Lucas, R.J.; Mills, A.; Wright, S.; Black, A.D.; Moot, D.J. 2015. Selection of sub clover cultivars for New Zealand dryland pastures. Proceedings of the New Zealand Grasslands Association 77: 203-210.

Mills, A.; Lucas, R.J.; Moot, D.J. 2014. 'MaxClover' grazing experiment: I. Annual yields, botanical composition and growth rates of six dryland pastures over nine years. Grass and Forage Science 70: 557. 570

Monks, D.; Moot, D.J.; Belgrave, B.; Rolston, M.P.; Caradus, J.R. 2016. Availability of seed for hill country adapted forage legumes. Grassland Research and Practice Series 16: 257-265.

Montgomery, D.C. 2013. Nested and split-plot designs. pp. 604-641. In: Design and analysis of experiments. $8^{\text {th }}$ Ed. United States: John Wiley \& Sons, Inc.

Moot, D.; Scott, W.; Roy, A.; Nicholls, A. 2000. Base temperature and thermal time requirements for germination and emergence of temperate pasture species. New Zealand Journal of Agricultural Research, 43: 15-25.

Moot, D.J.; Black, A.D.; Scott, W.R.; Richardon, J. 2003. Leaf development and dry matter production of subterranean clover cultivars in relation to autumn sward management. Grassland Research and Practice Series 11: 193-200.

OEPP/EPPO. 2014. PP 1/135 (4) Phytotoxicity assessment. pp. 265-273. In: Bulletin OEPP/EPPO Bulletin 3.

Sandral, G.A.; Dear, B.S. 2005. Weed control options in annual pasture legumes. Rural Industries Research and Development Corporation, Barton, ACT. 27 pp. Smetham, M.L. 2003. A review of Subterranean clover (Trifolium subterraneum L): Its ecology, and use as a pasture legume in Australasia. Advances in Agronomy 79: 303-350.

Stewart, A.; Kerr, G.; Lissaman, W.; Rowarth, J. 2006. Pasture and forage plants for New Zealand. Grassland Research and Practice Series 8: 1-128.

Teixeira, C.S.; Lucas, D.; Moot, D.J. 2015. Subterranean clover-literature Review: Project number 408090: Optimization of subterranean clover for dryland pastures in New Zealand. Sustainable Farming Fund 2015-2016.

\section{Winter rotation length effect on pasture production and animal \\ performance}

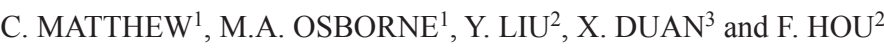
${ }^{1}$ Institute of Agriculture and Environment, Massey University, Private Bag 11222, Palmerston North 4442, New Zealand

${ }^{2}$ State Key Laboratory of Grassland Agro-ecosystems, College of Pastoral Agriculture Science and Technology, Lanzhou University, Lanzhou, 730020, China ${ }^{3}$ College of Animal Science and Technology, Yunnan Agricultural University, Kunming 650201, China c.matthew@massey.ac.nz

\section{Abstract}

Data comparing pasture production in winter pastures subject to 16,48 or 72 -day rotation lengths were recovered from experiments at Massey University to support teaching of grazing management. 'Farmlets' with 16 breeding ewes on 0.8 ha were run from 20112016, and he energy budgeting (MEB). The data illustrate: the roles of pasture cover and animal body weight as buffers to neutralise the impact of weather variability, the use of controlled cover release via the grazing rotation to partially meet winter feed deficit, and the potential value of MEB in systems research. Grass grown from May to September (early pregnancy to mid-lactation) was 3850,4220 and $4840 \mathrm{~kg} \mathrm{DM} / \mathrm{ha}$ for 16,48 and 72 day rotations, respectively. As a result of a reduction in herbage accumulation and the premature release of autumn-saved pasture to animals, the 16-day rotation failed to overwinter the animals in five of the 6 years, the exception being a winter with high pasture growth.

Keywords: winter rotation length, pasture growth rate, teaching pedagogy

\section{Introduction}

The majority of sheep and beef farms in New Zealand manipulate the grazing rotation length to store autumngrown feed as increased cover for release back to stock during periods of lower growth rates in winter. This winter management practice is often referred to as a 'controlled grazing system' (CGS) (Milligan 1981; Sheath et al. 1987). A key component of a CGS is the rationing of herbage intake of stock to levels that provide for body maintenance and pregnancy requirements, while ret.r. requirencents, which is surplus to the reque mass or 'cover'. Longer rotation lengths are achieved by keeping animals longer on a paddock during a grazing event and result in lower residual herbage mass after grazing. Paradoxically, even though herbage removal $(\mathrm{kg} \mathrm{DM} / \mathrm{ha})$ is increased when the rotation is lengthened, individual animals consume less feed/head/ day. This is because intake per animal is progressively reduced during successive days of a paddock grazing event as herbage height is lowered. Daily herbage intake of animals in a rotational grazing event can be monitored by calculating the herbage removed during grazing and dividing by the grazing intensity (animal. days/ha) (Matthews et al. 1999). Herbage consumption at a whole farm level (kg DM/ha/day) is thus determine by the stocking rate and rotation length.

The optimal rotation length depends on a range of site factors and so can vary greatly between farms. The key factor to plan rotation length is expected winter pasture growth rate; for a higher growth rate, increased stocking rate and decreased rotation length would be indicated and vice versa. Compared to set-stocked (continuously grazed) systems typically practiced in the middle of last century, a CGS allows more animals to be overwintered, enhancing farm carrying capacity and profitability. Little definitive research exists on the question of whether the higher stocking rate possible in a CGS than in a set-stocked wintering system arise simply from the reconciliation of mismatches in time between when the feed grows and when animals need it, or whether the longer grazing rotations in a CGS actually increase pasture growth rates.

To assist teaching of grazing management theory and practice at Massey University, a series of 'farmlets' have been maintained for about 25 years, where final year students working in a group create a small scale CGS on a block of $8 \times 0.1$ ha paddocks with electric fences for subdivision, running from early-May to late-September. Calculations on a per hectare basis are similar to those for a commercial farm. Typically, there are 5 or 8 student groups, each with their own farmlet. For 13 years (2004-2016), 2nd year veterinary students provided with farmlets for the teaching of grazing management theory and metabolic energy based feed budgeting. Farmlet teaching for veterinary students has involved a comparison of outcomes for farmlets commencing with a common herbage mass on 1 May, stocked at 20 ewes/ha, and running 16,48 or 72-day grazing rotation lengths until lambing in midAugust. Near the start of lambing, sheep are set-stocked until late September when they are weighed and the 